\title{
Economic Evaluation of Almond Farming. The Case of Adiyaman (Turkey)
}

\author{
İsmail UKAV \\ Department of Accounting and Tax, Kahta Vacational School Adiyaman University, Adiyaman, Turkey
}

\begin{abstract}
Almond consumption is constantly increasing due to its nutritious properties. Almond production is unable to meet the growing demand in Turkey and therefore the import is done. The almond growing in Turkey, which is one of the oldest fruit species in Anatolia, is becoming increasingly important. Almonds grown in all regions except the Eastern Black Sea coasts are noteworthy for the increase in production in Southeastern Anatolia Region. Adiyaman province, which is one of the provinces of the region, has come to the point of almond growing in many respects for studying. In this study, it is aimed to reveal the existing almond growing potential of Adiyaman. The potential in almond growing of Kahta, one of the districts of Adiyaman, is in the scope of this study, as well. In the study, benefiting from Turkey's Statistics Institute data, analysis and comments have been made In addition, almond cultivation data were obtained from producers and evaluated. Using the statistical data of TSI between the years 2009-2018, the area where almond is grown, the number of bearing and non bearing trees, yield and production amounts has been determined and the increase rates during the period have been calculated. Almond production area in Adiyaman increased by 35 times and amount of production increased by 26 times during the ten years examined. These values are higher in Kahta district. If these developments in almond cultivation continue, it is foreseen that it will make significant contributions to the national economy, increase in income and employment, and decrease in imports and gain foreign currency saving.
\end{abstract}

Keywords: Almond growing, almond production, Adiyaman, Kahta

DOI: $10.7176 / \mathrm{JESD} / 10-18-05$

Publication date:September $30^{\text {th }} 2019$

\section{Introduction}

The demand of foods that are considered to be healthy and suitable for fast consumption is increasing due to the difficulties of working life and the desire for healthy nutrition. Almond is one of the products that meet this demand. Changes in consumer awareness and health concerns are the main reasons for the increase in demand for nut crops such as almonds.

Almond; It is a fruit used in the food industry, confectionery, chocolate and pastry industry and almond oil is widely used in cosmetic and pharmaceutical industry. Almond (Prunus Dulcis) is a rosaceae family and its native land is southwest of Asia. It grows as long as the spring frosts don't give damage its flowers. Almond cultivation is carried out in hot climate and dry summer environments rather than cool and humid places in summer. There are bitter and sweet types of almond plant. Sweet almond seeds are consumed as a snack, used in the preparation of various foods, almond oil and almond flour. Bitter almonds are used as additives and fragrances in cosmetic industry.

It is very difficult to grow not crops due to factors such as special climatic requirements, specific physiology and special growing methods and special rootstock requirements according to soils. Despite the growing difficulty, the demand for almonds and almond products is constantly increasing in the world. World almond production and exports continue to increase due to the increasing demand for almonds. Both old markets and emerging markets are growing strongly in response to availability and acceptable price conditions. Within all markets, new innovative uses and traditional almond use will continue to increase demand as long as supply is available and prices remain attractive [1]

The countries that are prominent in the production of almonds have increased the total amount of product obtained from the unit area by researching new varieties and applying modern growing techniques. Compared to these countries, Turkey has many advantages in many ways such as soil, climate, irrigation water and so on [2]. Almond trees, which are usually planted as border trees at the edges of the field, are now formed in the form of enclosed almond orchards, which are modern breeding.

Almonds, which are in the scope of nut corps, are preferred due to their low labor requirements and cost advantages compared to other fruits. With the various supports provided by the ministries, almonds have been able to spread significantly throughout the country. For example, as a result of government support provided by the Ministry of Agriculture and Forestry, almond production has increased significantly, especially since the early 2000s, as a result of fuel, fertilizer and soil analysis, certified seed / seedling and standard seedling use [3]. In recent years, both walnut and almonds are in great demand for producers and non-agricultural sectors who want to invest in agriculture due to the fact that they can be substituted for each other as well as in the arboriculture sector. This has been influenced by a number of rural development projects aimed at increasing almond 
production[4].

The use of almond and almond by-products in the food, confectionery and cosmetics sectors increases the importance of the almond sector and necessitates solutions to its problems. $6.4 \%$ of our country's total fruit production is composed of nut corps. Almond constitutes $1.2 \%$ of the number of trees and $4.3 \%$ of the production amount among the nut corps [5].

Almond orchards, which have been concentrated commercially in the Aegean, Marmara and Mediterranean regions in recent years, have become the favorite product of producers in Southeast Anatolia Region in parallel with the increasing importance of the product. Adiyaman is also one of the important provinces where almonds are cultivated in the GAP region. Almond growing is preferred by Adiyaman producers because it is less selective in terms of soil and water demand compared to many other fruit species [6]. Another important factor in the region is the softening of the climate in the region by the Atatürk Dam Lake. In this respect, considering the climatic characteristics of Adiyaman, it has a suitable climate for almond growing and it is expected that almond growing will become more widespread in Adiyaman[7].

In this study, the general situation of Adiyaman in almond cultivation, which has made a great leap in almond production in recent years, was analyzed, its contributions to local and national economy were analyzed and recommendations were made. It is thought that the study will be important in terms of insufficient studies, conducted beforehand, and guiding the future researches.

\section{Material And Methods}

In this study, it is aimed to reveal the general structure of almond cultivation in Adryaman. To this end, statistics released by Turkey Statistical Institute (TSI) were used widely. In the study, first of all evaluations about growing areas of almond in Turkey, number of trees, amount of production and amount of production by cities have been made. In order to reveal the economic characteristics of almond production in Adryaman, the data have been examined. Adryaman's almond production area, production amount, fruit-bearing and non-fruit-bearing trees for the years 2009-2018 were also analyzed by districts, as well. Considering the importance of Kahta in the production of almonds, this district was examined in more detail. While the situation of the region in almond farming was revealed, face-to face talks were made with the producers and the evaluations of the producers were added to the study. In addition, various publications on the subject have been benefited.

\section{Results And Discussion}

\subsection{Almond Growing in Turkey}

Turkey, due to its geographical and climatic characteristics of the structure is the homeland of many fruit species $[8,9]$. Almonds, walnuts, pomegranates, pistachios, apples, hazelnuts, cherries, apricots and figs have emerged in Anatolia and have gained importance in recent years. Being a member of nut corps, almond has about 40 species and, 12 of these are grown in Turkey [10,11]. Almond, which has an important place in human nutrition in terms of health due to its content of fat, rich minerals and vitamins, has been increasing continuously in consumption and production in recent years $[11,12,13]$.

Almond is one of the oldest fruit species cultivated in Anatolia. Almond has a wide range of gene potential. However, almond hasn't received importance in Turkey for a long time and has usually been grown as border tree on the edge of the fields. Commercial almond cultivation is underdeveloped due to the fact that almond trees cannot be harvested regularly due to various climatic factors. As a result, the number of almond orchards remained inadequate until recent years. Almond growing, which has a very important place in world-wide nut corps production, is becoming increasingly common in Turkey, as well. It can be grown easily in all regions except Black Sea coastal areas. Almond cultivation, which was limited to Aegean, Mediterranean and South Eastern Anatolia Regions in the past, has become attractive due to the ability of almonds to adapt to difficult conditions and high demand in the market and it has started to expand with the establishment of plant nurseries in other regions in recent years. In this context, almond has become a shining star fruit in Southeastern Anatolia. When the region is evaluated in terms of climate, it is under the extension and influence of the Mediterranean climate. With this advantage, almond is preferred by producers because it is less selective in terms of soil and water demand compared to other fruit types such as pistachio and olives [6]. Therefore, in the coming years, increases in producer revenues may be seen especially for the producers, especially with the expansion of modern enclosure gardens established with suitable varieties $[14,15]$.

Almond production has continuously increased in recent years. Since the year 2010 almond production in Turkey has increased almost two times. It can be predicted that the increase in almond production will be realized at higher levels with the yield of the trees which do not produce fruit yet. According to TSI data for 2018, a total of 421914 hectares in 64 provinces in Turkey in almond growing is carried out, the amount of production of 100,000 tons and an average yield of almond $12 \mathrm{~kg} /$ tree. The total number of trees is 13.891 thousand, of which 8.490 thousand give fruit, but 5.401 thousand do not produce fruit yet. (Table 1). In terms of regions, the Mediterranean region is the first in almond production, the Aegean region is the second and the Southeastern 
Anatolian Region is the third. On the basis of provinces, the first five provinces are listed as follows. Mersin (14.141 tons), Adıyaman (11.747 tons), Antalya (6.358 tons), Çanakkale (5.098 tons) and Muğla (5.028 tons). Adiyaman's almond production is close to $12 \%$ in Turkey's almond production.

Table 1. Number of almond trees and production quantities in Turkey

\begin{tabular}{|r|c|c|c|c|}
\hline \multirow{2}{*}{ Years } & \multicolumn{2}{|c|}{ Number of trees (thousand) } & $\begin{array}{l}\text { Production } \\
(2000=100)^{*}\end{array}$ \\
\hline 2000 & Bearing trees & Non bearing trees & Production (Ton) & \\
\hline 2005 & 3.600 & 565 & 47.000 & 100 \\
\hline 2009 & 3.400 & 543 & 45.000 & 96 \\
\hline 2010 & 3.408 & 1.875 & 54.844 & 117 \\
\hline 2011 & 3.683 & 2.589 & 55.398 & 118 \\
\hline 2012 & 4.221 & 3.101 & 69.838 & 149 \\
\hline 2013 & 4.679 & 3.242 & 80.261 & 171 \\
\hline 2014 & 5.256 & 3.602 & 82.850 & 176 \\
\hline 2015 & 5.637 & 3.815 & 73.230 & 170 \\
\hline 2016 & 5.864 & 4.295 & 80.000 & 181 \\
\hline 2017 & 6.664 & 4.964 & 85.000 & 191 \\
\hline 2018 & 6.810 & 5.099 & 90.000 & 213 \\
\hline
\end{tabular}

Source: TSI, 2019. Crop Production Statistics. http://www.tuik.gov.tr/PreTabloArama.do

* Calculated by the author.

Demand for almonds is increasing every day in Turkey and because this demand cannot be met by domestic production almond is imported. Almond production area has been increasing rapidly around the world recently. The top almond producer countries in the world are the USA, Spain, Iran and Morocco.

\subsection{Almond Growing in Adıyaman}

The city center of Adiyaman is located at $37^{\circ} 45^{\prime}$ 'north latitude and $38^{\circ} 16^{\prime}$ east longitude and its altitude is $672 \mathrm{~m}$. The climate of the mountainous region to the north of the Anti-Taurus which divides Adiyaman from east to west is different from the climate of the region to the south. The south is dry and hot in summers, warm and rainy in winters; the north is dry and cool in summers, rainy and cold in winters. The prevailing winds in the province are in the north, northeast and northwest directions. In Adiyaman, temperatures rarely fall below zero in winter. The lowest temperatures of the year are between $-10^{\circ} \mathrm{C}$ and $-2{ }^{\circ} \mathrm{C}$. However, it was observed that the temperature did not fall below zero for some years. In summer, the average temperatures are $28^{\circ} \mathrm{C}$ to $38^{\circ} \mathrm{C}$ and maximum temperatures range from $35^{\circ} \mathrm{C}$ to $47^{\circ} \mathrm{C}$. The average annual rainfall is $674 \mathrm{~mm}$. With these characteristics, the climate of the province, which is a bridge between Eastern Anatolia and the Mediterranean Regions, is different from other provinces in the region. Furthermore, after the formation of the Atatürk Dam Lake area, there has been a softening and an increase in the humidity rate in the climate of the province [17].

Climate diversity is an effective factor in the growing of many crops in Adiyaman. Almond is one of these products. Adiyaman province is more advantageous than other almond growing provinces in terms of its location and climate. Considering the climatic characteristics of the province, the effect of late spring frosts, which are an important factor in almond cultivation, the desired high temperatures during the fruit filling period, the availability of underground water resources for irrigation, which affect yield and quality, have an effective and economic shape, existence of large-scale land suitable for efficient and economic use of agricultural mechanization, being close to the institutions and organizations conducting research in almonds in order to monitor the research on almonds and exchange information are some of these advantages [18]. In addition, after many years of field cultivation in Adiyaman producers have turned to horticultural agriculture. Almond, olive and walnut orchards are established as an alternative product [19]. In terms of input costs, almond growing was found to be the most advantageous among the nut corps [20]. Therefore, especially after the restriction of tobacco in the region, producers turned to alternative products and started to make an important contribution to both the local people and the national economy.

Almond growing is carried out in all the provinces of Southeastern Anatolia Region, which is at the third place in almond growing in Turkey (Table 2). According to 2018 statistics, 24,742 tons of almonds are produced in 130,045 decares of land in the Southeastern Anatolia Region; yield per tree $10 \mathrm{~kg} /$ tree; the number of fruitbearing trees is 2,579,510; the number of non bearing trees is 1.661.971 and the total number of trees is 4.241 .481 (TSI, 2019). 
Table 2. Number of almond trees, yield and production amount in Southeastern Anatolian Region (2018)

\begin{tabular}{|l|r|r|r|r|r|r|}
\hline Cities & \multicolumn{1}{l}{$\begin{array}{l}\text { Number of } \\
\text { bearing trees }\end{array}$} & $\begin{array}{l}\text { Number of non } \\
\text { bearing trees }\end{array}$ & $\begin{array}{l}\text { Area } \\
\text { (Decar) }\end{array}$ & $\begin{array}{l}\text { Yield } \\
(\mathrm{Kg} / \text { tree })\end{array}$ & $\begin{array}{l}\text { Production } \\
\text { (Ton) }\end{array}$ & $\begin{array}{l}\text { Share in total } \\
\text { production } \\
(\%) *\end{array}$ \\
\hline Adryaman & 1.204 .200 & 819.488 & 58.430 & 10 & 11.747 & 47.48 \\
\hline Batman & 33.530 & 25.910 & 2.855 & 15 & 489 & 1.98 \\
\hline Diyarbakır & 339.352 & 97.255 & 7.910 & 9 & 2.899 & 11.72 \\
\hline Gaziantep & 188.346 & 38.482 & 10.388 & 14 & 2.673 & 10.80 \\
\hline Kilis & 51.650 & 9.558 & 2.482 & 10 & 498 & 2.01 \\
\hline Mardin & 158.803 & 100.290 & 7.347 & 11 & 1.702 & 6.88 \\
\hline Siirt & 29.115 & 6.881 & 614 & 6 & 181 & 0.73 \\
\hline Şanliurfa & 568.759 & 561.279 & 39.639 & 8 & 4.515 & 18.25 \\
\hline Şirnak & 5.755 & 2.828 & 380 & 7 & 38 & 0.15 \\
\hline Total & 2.579 .510 & 1.661 .971 & 130.045 & 10 & 24.742 & 100.00 \\
\hline
\end{tabular}

Source: TSI, 2019. Crop Production Statistics $\underline{\text { http://www.tuik.gov.tr/PreTabloArama.do }}$

*Calculated by the author

Adiyaman is the province where almond cultivation is most intense in the GAP Region. The province ranks first in terms of number of trees, area and production. The share of Adiyaman almond production in the total production of the region is $47.48 \%$ (Table 2). Therefore, Adiyaman performs almost half of the almond production in the region. In addition, with the return of non-bearing trees to yield in the coming years, the weight of the province in the region may increase. Adıyaman is followed by Şanlıurfa, Diyarbakır and Gaziantep with their shares in production respectively. Almond yield per tree in Adiyaman is the same as the region average (10 kg / tree). The gardens established in the region are usually Ferragnes and Ferraduel almond varieties grafted to bitter almond rootstock. In addition to these, there are also gardens which are established with scented seedlings grafted on rootstocks which are almond hybrid. Since the starting age of yield of saplings that are grafted to bitter almond rootstock is later than clonal rootstocks and garden's not being irrigated, affects negatively almond yield in the region [18].

Since 2018, 11,747 tons of almonds have been produced from 1,204,200 bearing trees of almond in Adiyaman (Table 3). The production will increase with the trees that have not produced fruit yet. 54.13\% of the almonds produced in Adiyaman belongs to Kahta. In this respect, Kahta district stands out in the production of almonds. Kahta is followed by Gölbaşı (22.24\%) and Besni (15.98\%).

Table 3. Almond tree numbers and production amount in Adiyaman province (2018)

\begin{tabular}{|l|r|r|r|r|r|r|}
\hline Districts & $\begin{array}{l}\text { Number of } \\
\text { bearing trees }\end{array}$ & $\begin{array}{l}\text { Number of non } \\
\text { bearing trees }\end{array}$ & $\begin{array}{l}\text { Area } \\
\text { (Decar) }\end{array}$ & $\begin{array}{l}\text { Yield } \\
(\mathrm{Kg} / \text { tree })\end{array}$ & $\begin{array}{l}\text { Production } \\
\text { (Ton) }\end{array}$ & $\begin{array}{l}\text { Share in total } \\
\text { production }(\%) *\end{array}$ \\
\hline Besni & 192.000 & 167.720 & 12.710 & 10 & 1.877 & 15.98 \\
\hline Gerger & 14.080 & 25.155 & 1.020 & 9 & 126 & 1.07 \\
\hline Gölbaş1 & 246.700 & 18.000 & 7.500 & 11 & 2.613 & 22.24 \\
\hline Kahta & 650.358 & 331.405 & 28.000 & 10 & 6.359 & 54.13 \\
\hline Merkez & 55.880 & 222.320 & 6.500 & 8 & 455 & 3.87 \\
\hline Samsat & 10.300 & 16.450 & 800 & 10 & 101 & 0.9 \\
\hline Sincik & 2.358 & 2.662 & 140 & 8 & 19 & 0.2 \\
\hline Tut & 26.524 & 33.276 & 1.560 & 7 & 173 & 1.47 \\
\hline Çelikhan & 6.000 & 2.500 & 200 & 4 & 24 & 0.2 \\
\hline Total & 1.204 .200 & 819.488 & 58.430 & 10 & 11.747 & 100 \\
\hline
\end{tabular}

Source: TSI, 2019. Crop Production Statistics

https://biruni.tuik.gov.tr/medas/?kn=92\&locale $=\operatorname{tr}$

*Calculated by the author.

Table 4 shows the developments in the almond production area of Adiyaman districts over the years. The production area increased from 1662 decares in 2009 to 58,430 decares in 2018. In the last decade, there has been an increase of approximately 35 times in the field of almond production. In the aspect of production area, Kahta district is first with 28.000 decares, and it is followed by Besni and Gölbaşı districts. 
Table 4. Almond production area (decare) in Adiyaman by year

\begin{tabular}{|c|c|c|c|c|c|c|c|c|c|c|}
\hline Years & Besni & Gerger & G jlbaşı & Kahta & Central & SSamsat & Sincik & Tut & Şelikhan & Total \\
\hline 2009 & 731 & 29 & 644 & 200 & 0 & 50 & 8 & 0 & 0 & 1.662 \\
\hline 2010 & 752 & 32 & 820 & 500 & 322 & 25 & 8 & 32 & 0 & 2.491 \\
\hline 2011 & 752 & 12 & 820 & 1150 & 475 & 45 & 8 & 300 & 0 & 3.562 \\
\hline 2012 & 763 & 12 & 832 & 1167 & 690 & 46 & 8 & 365 & 0 & 3.883 \\
\hline 2013 & 2772 & 277 & 2512 & 3468 & 2.016 & 40 & 15 & 368 & 0 & 11.468 \\
\hline 2014 & 2772 & 277 & 2620 & 8468 & 2.500 & 35 & 35 & 542 & 0 & 17.249 \\
\hline 2015 & 3772 & 527 & 2620 & 12968 & 4.500 & 120 & 35 & 800 & 0 & 25.342 \\
\hline 2016 & 7250 & 541 & 4695 & 20219 & 5.655 & 450 & 65 & 900 & 200 & 39.975 \\
\hline 2017 & 11447 & 922 & 5922 & 22468 & 5.534 & 634 & 132 & 1.466 & 189 & 48.714 \\
\hline 2018 & 12710 & 1020 & 7500 & 28000 & 6.500 & 800 & 140 & 1.560 & 200 & 58.430 \\
\hline
\end{tabular}

Source: TSI, 2019. Crop Production Statistics

https://biruni.tuik.gov.tr/medas/?kn=92\&locale=tr

Almond is produced in all districts of Adiyaman. Almond production increased from 448 tons in 2009 to 11,747 tons in 2018 (Table 5). Almond production increased by 26 times in the decade examined. In 2018, Kahta had the highest production with 6359 tons and Sincik had the lowest production with 19 tons. Gölbaş1 and Besni are the districts where almond production is concentrated.

Table 5. Almond production in the province of Adiyaman by year (ton)

\begin{tabular}{|c|c|c|c|c|c|c|c|c|c|c|}
\hline Years & Besni & Gerger & Gölbaşı & Kahta & Central & Samsat & Sincik & Tut & Çelikhan & Total \\
\hline 2009 & 53 & 50 & 165 & 72 & 47 & 0 & 2 & 29 & 30 & 448 \\
\hline 2010 & 55 & 51 & 165 & 77 & 72 & 6 & 2 & 29 & 30 & 487 \\
\hline 2011 & 55 & 51 & 182 & 134 & 64 & 11 & 4 & 82 & 15 & 598 \\
\hline 2012 & 64 & 49 & 207 & 164 & 71 & 12 & 5 & 82 & 15 & 669 \\
\hline 2013 & 81 & 59 & 519 & 235 & 125 & 13 & 6 & 89 & 14 & 1.141 \\
\hline 2014 & 185 & 33 & 477 & 348 & 140 & 11 & 8 & 32 & 3 & 1.237 \\
\hline 2015 & 250 & 43 & 512 & 588 & 267 & 13 & 10 & 93 & 24 & 1.800 \\
\hline 2016 & 614 & 121 & 717 & 1441 & 480 & 53 & 13 & 103 & 34 & 3.576 \\
\hline 2017 & 1220 & 111 & 652 & 2170 & 196 & 55 & 14 & 149 & 26 & 4.593 \\
\hline 2018 & 1877 & 126 & 2613 & 6359 & 455 & 101 & 19 & 173 & 24 & 11.747 \\
\hline
\end{tabular}

Source: TSI, 2019. Crop Production Statistics

https://biruni.tuik.gov.tr/medas/?kn=92\&locale=tr

\subsection{Almond Growing in Kahta}

Kahta, one of the districts of Adiyaman, is at the forefront in almond growing as it is in many aspects in the agricultural field. In recent years, modern gardens and standard varieties such as Ferragnes, Ferraduel and Texas have been established in the region for the development of almond cultivation [7]. For this reason, it is important to consider the almond growing of Kahta district separately. Kahta district has made a big leap in almond growing. While only 200 decares of almonds were grown in 2009, the production area increased to 28,000 decares in 2018 (Table 6). While the number of bearing trees was 6500 in 2009, it raised to 650,358 in 2018. There has been a 100 times increase in the number of bearing trees. A similar trend was observed in the amount of almond production. Production, which was only 72 tons in 2009, reached 6,359 tons in 2018. This means about a 90 times increase. In the coming years, the amount of production will increase with the start of yielding trees that are non bearing. 
Table 6. Almond tree number and production amount in Kahta district by years

\begin{tabular}{|c|c|c|c|c|c|c|}
\hline Years & $\begin{array}{l}\text { Number of } \\
\text { bearing trees }\end{array}$ & $\begin{array}{l}\text { Number of non } \\
\text { bearing trees }\end{array}$ & $\begin{array}{l}\text { Area } \\
\text { (Decares) }\end{array}$ & $\begin{array}{l}\text { Yield } \\
\text { (Kg/tree) }\end{array}$ & $\begin{array}{l}\text { Production } \\
\text { (Ton) }\end{array}$ & $\begin{array}{l}\text { Production index* } \\
(2009=100)\end{array}$ \\
\hline 2009 & 6.500 & 4.000 & 200 & 11 & 72 & 100 \\
\hline 2010 & 7.000 & 14.500 & 500 & 11 & 77 & 107 \\
\hline 2011 & 10.300 & 28.750 & 1.150 & 13 & 134 & 186 \\
\hline 2012 & 12.600 & 26.400 & 1.167 & 13 & 164 & 228 \\
\hline 2013 & 18.900 & 66.900 & 3.468 & 12 & 235 & 326 \\
\hline 2014 & 29.000 & 176.500 & 8.468 & 12 & 348 & 483 \\
\hline 2015 & 49.000 & 296.000 & 12.968 & 12 & 588 & 817 \\
\hline 2016 & 139.544 & 535.383 & 20.219 & 10 & 1.441 & 2.001 \\
\hline 2017 & 236.644 & 509.885 & 22.468 & 9 & 2.170 & 3.014 \\
\hline 2018 & 650.358 & 331.405 & 28.000 & 10 & 6.359 & 9.082 \\
\hline
\end{tabular}

Source: TSI, 2019.Crop Production Statistics https://biruni.tuik.gov.tr/medas/?kn=92\&locale=tr

*Calculated by the author

The Central Institute of Agricultural Credit Cooperatives established the Research Institute for Not Corps in Kahta Organized Industrial Zone. The Institute conducts studies for marketing and exporting almonds. With this aspect, the marketing problem for the almonds produced by the producers is eliminated. Not only Adiyaman but also Şanlıurfa, Diyarbakır, Malatya and Kahramanmaraş can benefit from the Almond and Pistachio Operating Facility established under the Agricultural Credit Cooperative. Almonds and Pistachios as well as walnuts can be processed in the facility. The facility also produces and markets products such as almond oil, almond flour, confectionery and mash for the processing of almonds. As an example, some sweet shops in Kahta have started to produce almond baklava as an alternative.

Almond consumption is increasing all over the world. Demand for almonds in Turkey is increasing and since the domestic production doesn't meet the consumption, import for almond is needed. Therefore, almond cultivation is an area of economic benefit for producers. By meeting the domestic demand and focusing on exports, significant contributions can be made to the national economy. For this reason, Adiyaman may have an important advantage in meeting almond demand.

Going to branding in almonds is an important stage in terms of creating added value to the product. In this process, Adiyaman Chamber of Commerce and Industry's application for registration of geographical signs for almonds is an important step. The positive result of this process will increase Adiyaman's importance in terms of almond growing. If Malatya is known as apricot and Gaziantep is the brand city in pistachio, Adiyaman can be referred to as brand city for almond. In this way, almond-related industrial investments can increase in the nut corps sector, and this situation can also contribute to employment. Local people who go to other regions as seasonal workers will now be able to work and maintain their lives in their own city with the development of almond cultivation.

Interesting and rational practices regarding the newly established almond orchards are also on the agenda. For example, sheep farming in almond gardens can be done. For sheep, meeting forage needs by planting forage crops between trees in the garden can reduce livestock production costs. Thus, animal fertilizer needs of almond trees may be met by itself. Therefore, costs can be reduced by using fewer versions, fertilizers and pesticides. As a result, the increase in meat production will contribute to the red meat deficit of the national economy.

The following situations were identified during the interviews with almond growers.

Expectation from almond growing in the region is quite high. Therefore, great importance is given to this field. Increasing of almond production continues. Growers especially prefer Ferragnes and Ferraduel varieties. Producers who are aware of the efficiency increasing feature of irrigation make the necessary investments related to irrigation. Almond growers said that this year because of excessive rainfall in the flowers of almonds shed before ripening and therefore yield will decrease. They also stated that eurytomaamygdali, red spider and aphids were found as the almond pests.

Almond harvest starts in August in the region just like in Southeastern Anatolia. The green shell is cracked in the fruits that reach maturity on the tree and partially dried and undergoes color change. This is a sign of harvest maturity in almonds. It is preferred to pour the fruits with a normal shake. In addition, pole branches are shaken and the ripe almonds are poured from the tree. Harvesting by machine is not preferred much because of the concern that it may damage the roots of the tree. Then, the separation of green shells is provided in machines called patoz. Since the amount of moisture of the harvested fruits is high, it is important that they are dried and kept up to certain humidity. The fruits collected by the producers are spread thinly for 4-5 days under the sun and mixed frequently and the moisture level is controlled. Almonds that are controlled and whose humidity level is at the desired level are stored or immediately sold to the Almond and Pistachio Plant. 


\section{Conclusion And Suggestions}

Significant improvements in almond production have been seen in Turkey in recent years. Particularly, Adiyaman has become the province that makes the most mention of almond production. In this study, it is aimed to reveal the current situation of Adiyaman in almond growing in various aspects. Significant increases in the amount of almond production have emerged due to the support provided by the state and the producers' search for alternative products. While the increase of almond production area is 35 times in Adiyaman, the increase in production is 26 times. The average yield per tree was determined to be $10 \mathrm{~kg}$. In the evaluation made on the basis of districts, it was observed that Kahta district took the first place in almond growing. Almond production in Kahta increased by 90 times during the period examined. It is foreseen from the data that almond production will continue to increase in the coming years. The Almond and Pistachio Plant, established in the Organized Industrial Zone in Kahta, where a large part of almond production takes place, is thought to solve the producer's almond processing and marketing problem to a great extent.

Based on these assessments, it is useful to consider the following issues related to the development of Adiyaman almond cultivation: Almonds with high nutritional value is one of the important food products in human nutrition. However, production is not at a level to meet consumption. Production is increasing day by day with the support and incentives provided by the state to the almond producer.

However, the use of contemporary techniques in almond farming and mechanization should be given importance to research and projects. Promising developments are expected for the future of almond cultivation in the region and the use of almond products in various fields. This will not only provide consumers with more affordable prices and qualified products, but will also contribute to higher income levels and employment. In order to increase the production of almonds, it should be provided the right variety, high quality and healthy seedlings that are flowering late and not to be damaged by late spring frost, breeding problems of seedlings should be solved, farmers should be supported for the establishment of closing gardens, producers should take an active role in the market and other production activities. In order to increase the export potential, efforts towards foreign markets should be given importance.

New almond orchards installed in the region can lead to an increase in the production of insufficient almonds in our country and the marketing of high quality almonds to the world markets. In the provinces where any fruit is grown intensively, the industry of that fruit is also developing. Almond is a fruit consumed fresh and as dried fruit. Initiatives for the almond industry in Adryaman will both be a solution to the marketing problem and the price losses that producers may experience in product sales will be prevented. Almond processing industry, which is used as raw material (cake, chocolate, etc.) in many products, especially in the confectionery industry, should also be increased in parallel with production. Countries that dominate the almond market should be taken as an example [1].

In short; In order to develop almond farming in the region, producer unions and cooperatives should be established, marketing and storage activities should be given importance and switching to modern farming techniques are of great importance.

\section{References}

1. Lovin, C., Bell, M. (2010), An Almond Marketing Manual For Afghanistan: Key Concepts, University of California, College of Agricultural \& Environmental Sciences, Project funded by European Union February, p30.

2.Kaşka,N., Ak, B.E., Açar, İ. (1999), Almond Production, Growing and Its Future in The World and GAP Area. GAP 1. Agriculture Congresses, 26-28 May 1999, Şanliurfa.

3. Yazar, F., Secer, A. (2019), Evaluatıon Of Almond Marketıng Organızation In The Eastern Mediterranean Region Of Turkey, Black Sea Journal Of Public And Social Science, 2(2): 60-68.

4. Pezikoğlu, F., Öztürk, M., Tosun, İ. (2012), Production and Marketing of Walnut and Almond, and Effect of Private Afforestation Project, 10. National Agricultural Economics Congresses 5-7 September 2012. Konya/Turkey pp 839-843.

5. Ministry of Forestry and Water Affairs,(2013), Badem Eylem Plan1, 2013. pp40.

6. Oğuz, H.İ., Y1lmaz, A., Ukav, İ. (2011), Potential of Almond (Prunus Amygdalus Batsch.) Growing, Production and Marketing in Southeastern Region of Anatolia Provinces. pp274-280.Türkiye VI.National Horticulture Congresses, Harran University Agriculture Faculty, 4-8 October 2011, Şanlıurfa.

7. Şimşek, M., Gülsoy, E. (2017), A General View of Almond (PrunusamygdalusL.) Production Potantial of Southeastern Anatolia Region, Iğdır Üniversitesi Iğdır University. Journal. Institue. Sci. \& Tech. 7(3): 19-29.

8. Gerçekçioğlu R, Bilgener Ş, Soylu A. (2014), Genel Meyvecilik. Nobel Akademik Yayıncılık, Geliştirilmiş 4. Basım, 498 s., 2014. İstanbul.

9. Şimşek M, Kara A. (2016), Diyarbakır Fruit Growing Potential An Overview. International Diyarbakır Symposium ,2-5 November 2016, Diyarbakır/TURKEY.

10. Şimşek M, Osmanoğlu A, Taş Z. (2010), Fruıt Performances Of The Selected Almond (PrunusAmygdalus L.) 
Types In Cermık District. Harran University, Journal of Agriculture Faculty, 2010. 14(2): 29-37.

11. Gülsoy E, Balta F. (2014), Determination of Protein, Oil and Fatty Acid Contents of Some Selected Almond (Prunusamygdalus Batch) Genotypes from Karacasu and Bozdoğan Yenipazar of Aydın Province, Iğdır University. Journal. Institue. Sci. \& Tech. 4(1): 9-14.

12. Beyhan Ö, Aktaş M, Yılmaz N, Şimşek N, Gerçekcioğlu R. (2011), Determination of Fatty Acid Composition in Seed Oils of Some Important Almond (Prunusamygdalus L.) Genotypes Growing in Tokat Province and Eagean Region,Turkey", Journal of Medicinal Plants Research (ISI), Vol 5 (19), 4907-4911.

13. Gülsoy E, Ertürk E.Y, Şimşek M. Local Almond (Prunusamygdalus L.) Selections in Turkey, (2016), Yüzüncü Y1l University Journal of Agricultural Sciences, 2016. 26(1): 126-134.

14.https://acikders.ankara.edu.tr/pluginfile.php/6181/mod

resource/content $/ 0 / \% 2$ BBADEM $\% 20$ YET $\% \mathrm{C} 4 \% \mathrm{~B} 0 \% \mathrm{C} 5 \% 9 \mathrm{ET} \% \mathrm{C} 4 \% \mathrm{~B} 0 \mathrm{R} \% \mathrm{C} 4 \% \mathrm{~B} 0 \mathrm{C} \% \mathrm{C} 4 \% \mathrm{~B} 0 \mathrm{~L} \% \mathrm{C} 4 \% \mathrm{~B} 0 \% \mathrm{C} 4 \% 9 \mathrm{E} \% \mathrm{C} 4 \% \mathrm{~B} 0 . \mathrm{p}$ df Accessed : 20.05.2019.

15. Küden, A.B. (2016), Ülkemizde Badem Yetiştiriciliği Önemi ve Geleceği, Antepfıstı̆̆ı Araştırma Dergisi, (5):48-52.

16. TSI (Turkey's Statistics Institute),2019. Crop Production Statistics Accessed:04.07.2019. Availablehttp://www.tuik.gov.tr/PreTabloArama.do.

17. Adiyaman Governorate, (2019), Accessed : 24.03.2019. Available: http://www.adiyaman.gov.tr/iklim.

18. Yılmaz, A. Bademin Merkezi Olma Yolunda Adıyaman, (2016), Antepfıstığı Araştırma Dergisi (5): 10-13.

19. Oğuz, H.İ. Adıyaman'da Meyvecilik Sorunları Üzerine Bir Araştırma 4.Medeniyetler Kavşağı Adıyaman Sempozyumu 31 May-2 June 2012. pp117-127.

20. Ukav İ. Production Inputs And Profitability Indicators Of The Nut Crops (Pistachios, Almond And Walnuts) Produced In Adiyaman. 5th International Participation Soil and Water Resources Congress, 2017. 1(1), 761770. 